Dwoskin LP, Sumithran SP, Zhu J, Deaciuc AG, Ayers JT, Crooks PA (2004). Subtype-selective nicotinic receptor antagonists: potential as tobacco use cessation agents. Bioorg Med Chem Lett 14: 1863-1867.

Dwoskin LP, Wooters TE, Sumithran SP, Siripurapu KB, Joyce BM, Lockman PR et al (2008a). N, $N^{\prime}$ Alkane-diyl-bis-3-picoliniums as nicotinic receptor antagonists: inhibition of nicotine-induced dopamine release and hyperactivity. J Pharmacol Exp Ther 326: 563-576.

Molles BE, Maskos U, Pons S, Besson M, Guiard P, Guilloux JP et al (2006). Targeted in vivo expression of nicotinic receptors in mouse brain using lentivira expression vectors. J Mol Neurosci 30: 105-106.

Neugebauer NM, Zhang Z, Crooks PA, Dwoskin LP Bardo MT (2006). Effect of a novel nicotinic receptor antagonist, $N, N^{\prime}$-dodecane-1,12-diyl-bis-3-picolinium dibromide, on nicotine self-administration and hyperactivity in rats. Psychopharmacology 184:426-434.

Rahman S, Neugebauer NM, Zhang Z, Crooks PA Dwoskin LP, Bardo MT (2007). The effects of a novel nicotinic receptor antagonist $N, N$ dodecane1,12-diyl-bis-3-picolinium dibromide (bPiDDB) on acute and repeated nicotine-induced increases in extracellular dopamine in rat nucleus accumbens. Neuropharmacology 52: 755-763.

Neuropsychopharmacology Reviews (2009) 34, 244-246; do: I0.1038/npp.2008.157

\section{RNA editing as a therapeutic target for CNS disorders}

The conversion of adenosine to inosine (A-to-I) by RNA editing is a widespread RNA processing event by which genomically encoded sequences are altered through site-specific deamination of adenosine residue(s) by a family of enzymes referred to as adenosine deaminases that act on RNA (ADARs). Notable targets of RNA editing in the CNS include transcripts encoding subunits of the AMPA and kainate (KA) subtypes of glutamate receptor, the $\alpha 3$ subunit of the $\mathrm{GABA}_{\mathrm{A}}$ receptor, the serotonin $2 \mathrm{C}\left(5 \mathrm{HT}_{2 \mathrm{C}}\right)$ receptor, and the $\mathrm{K}_{\mathrm{v}} 1.1$ voltage-gated potassium channel. RNA editing can modulate the functional properties of the encoded protein products and variations in the editing of glutamate receptor subunit and $5 \mathrm{HT}_{2} \mathrm{C}$ mRNAs have been observed in several CNS disorders (Rula and Emeson, 2007), suggesting that modulation of RNA editing in the nervous system could represent a therapeutic strategy for the treatment of nervous system dysfunction.
A failure to edit GluR2 transcripts results in $\mathrm{Ca}^{2+}$-permeable AMPA receptors that can lead to excitotoxicity. Recent studies have observed a significant reduction in $\mathrm{Q} / \mathrm{R}$ site editing for affected motor neurons isolated from patients with amyotrophic lateral sclerosis, suggesting that glutamatergic excitotoxicity may underlie the selective neuronal death of these motor neurons (Kwak and Kawahara, 2005). RNA editing of another site within GluR2 transcripts (R/G site) alters both the recovery rate and desensitization kinetics of AMPA receptors containing edited subunits (Rula and Emeson, 2007) and increased editing has been observed in the hippocampus of patients with temporal lobe epilepsies (Vollmar et al, 2004). Significant alterations in KA receptor editing and ADAR2 protein expression also have been seen following seizures in humans and rats, and genetically modified animals solely expressing a nonedited GluR6(Q) subunit demonstrate increased susceptibility to KA-induced seizures (Vissel et al, 2001), suggesting KA receptor editing may modulate seizure vulnerability.

Editing of $5 \mathrm{HT}_{2 \mathrm{C}}$ receptor transcripts can generate up to 24 receptor isoforms that not only have distinct functional properties affecting constitutive activity and receptor/G-protein coupling, but also differ in their pattern of CNS expression (Rula and Emeson, 2007). Altered editing patterns have been observed in suicide victims with a history of major depression and in response to antidepressant treatment (Niswender et al, 2001; Gurevich et al, 2002), suggesting that editing may be involved in affective disorders and the maintenance of appropriate serotonergic neurotransmission.

Although no conclusive data have demonstrated that changes in RNA editing are causal for human brain disorders, the role of ADARs in the function of numerous receptors/channels highlights the potential for ADAR activity as a future target for the treatment of CNS dysfunction. Therapeutic modulation of A-to-I editing patterns for specific substrates is complicated by the fact that only two ADAR proteins have been shown to catalyze all known editing events in mammals, predicting that broad alterations in ADAR activity could result in untoward effects. Observations that RNA editing changes in CNS disorders may occur in specific brain regions, or even subpopulations of neurons, suggest that substrate- or region-selective approaches to modify editing represent more promising areas of research for the treatment of CNS disorders.

\section{Michael V Morabito ${ }^{1,2}$ and \\ Ronald B Emeson ${ }^{1,2}$}

${ }^{1}$ Department of Pharmacology, Vanderbilt University, Nashville, TN, USA and

${ }^{2}$ Center for Molecular Neuroscience, Vanderbilt University, Nashville, TN, USA

E-mail: ron.emeson@vanderbilt.edu

\section{DISCLOSURE/CONFLICT OF INTEREST}

The authors declare that except for income received from their primary employer, no financial support or compensation has been received from any individual or corporate entity over the past 3 years for research or professional service and there are no personal financial holdings that could be perceived as constituting a potential conflict of interest.

Gurevich I, Tamir H, Arango V, Dwork AJ, Mann JJ, Schmauss C (2002). Altered editing of serotonin $2 \mathrm{C}$ receptor pre-mRNA in the prefrontal cortex of depressed suicide victims. Neuron 34 349-356.

Kwak S, Kawahara Y (2005). Deficient RNA editing of GluR2 and neuronal death in amyotropic lateral sclerosis. J Mol Med 83: 110-120.

Niswender CM, Herrick-Davis K, Dilley GE, Meltzer HY, Overholser JC, Stockmeier CA et al (2001). RNA editing of the human serotonin 5-HT2C receptor: alterations in suicide and implications for serotonergic pharmacotherapy. Neuropsychopharmacology 24: 478-491.

Rula EY, Emeson RB (2007). Mouse models to elucidate the functional roles of adenosineto-inosine editing. Methods Enzymol 424: 333-367.

Vissel B, Royle GA, Christie BR, Schiffer HH, Ghetti A, Tritto T et al (2001). The role of RNA editing of kainate receptors in synaptic plasticity and seizures. Neuron 29: 217-227.

Vollmar W, Gloger J, Berger E, Kortenbruck G, Kohling R, Speckmann EJ et al (2004). RNA editing (R/G site) and flip-flop splicing of the AMPA receptor subunit GluR2 in nervous tissue of epilepsy patients. Neurobiol Dis 15 371-379.

Neuropsychopharmacology Reviews (2009) 34, 246; doi: | 0.1 038/npp.2008. 159 